\title{
Early Evaluation of Camu-Camu Subsamples in Transition Savanna/Forest Area
}

\author{
Luís Felipe Paes de Almeida ${ }^{1}$, Kaoru Yuyama ${ }^{1}$, Edvan Alves Chagas ${ }^{2}$, Ricardo Manuel Bardales Lozano ${ }^{4}$, \\ Teresinha Costa Silveira Albuquerque ${ }^{2}$, Carlos Abanto Rodriguez ${ }^{3} \&$ Fernando Barreto Queiroz $^{2}$ \\ ${ }^{1}$ Instituto Nacional de Pesquisas da Amazônia, Brazil \\ ${ }^{2}$ Empresa Brasileira de Pesquisa Agropecuária, Brazil \\ ${ }^{3}$ Instituto de Investigaciones da La Amazonia Peruana, Perú \\ ${ }^{4}$ Rede Bionorte (Multinsitutional programme of Amazon), Brazil \\ Correspondence: Luís Felipe Paes de Almeida, Instituto Nacional de Pesquisas da Amazônia, Manaus, AM, \\ 69067-375, Brazil. Tel: 95-8100-0406. E-mail: luisfelipe.almeida@gmail.com
}

Received: August 10, 2014 Accepted: September 9, 2014 Online Published: October 15, 2014

doi:10.5539/jas.v6n11p178 URL: http://dx.doi.org/10.5539/jas.v6n11p178

\begin{abstract}
Camu-camu (Myrciaria dubia (Kunth) McVaugh) is an indigenous fruit of the floodplain and riparian forests of the Amazon region. In Brazil, Roraima state has appropriate conditions for this fruit production. Cultivation outside the floodplains is an alternative to increase the availability of fruits, since flowering occurs almost all year round, and fruit bearing coincides with the end of the dry season and early rain season. The objective of this study was to evaluate the vegetative development of 6 camu-camu subsamples selected from the Instituto Nacional de Pesquisas da Amazônia- INPA (Amazonas state), in a savanna region near Boa Vista city (Roraima, Brazil). The experiment was conducted at the Serra da Prata Experimental Station of the Empresa Brasileira de Pesquisa Agropecuária (EMBRAPA), with a climate type Am according to Köppen climate classification. Four parameters were evaluated for the growth analysis, the basal stem diameter $(\mathrm{mm})$, the plant height $(\mathrm{cm})$, and numbers of basal and terminal shoots, as well as the numbers of flowers and fruits. Measurements were made at 90 days intervals in order to define the growth curve of each subsample for 30 months Based on the parameters of vegetative growth and early flowering, we recommend the UAT 1096-5 subsample with the best vegetative development for transition forest/Savanna area, presenting moreover higher number of terminal shoots, greater height, and early flowering than the remaining camu-camu subsamples. At 30 months after planting, the UAT 1896-7 and UAT 0796-8 subsamples showed no statistical difference from UAT 1096-5 regarding the number of terminal shoots, but showed slightly lower height, with a statistically significant difference. The UAT 1596-7, UAT 1796-7, and URUBU-2 subsamples showed the lowest number of terminal shoots, although UAT 1596-7 presented greater height than the others. In relation to precocity, peak flowering occurred in January, 30 months after planting, with the UAT 0796-8 and UAT 1096-5 subsamples excelling over others, with 500 and 435 flowers in total, respectively.
\end{abstract}

Keywords: plant growth, Myrciaria dubia (Kunth) Mc Vaugh, upland production, Brazil

\section{Introduction}

Camu-camu (Myrciaria dubia (Kunth) Mc Vaugh) is an indigenous fruit of the floodplains forests that form dense stands along oxbow lakes of river courses of the Amazon region [Figure 1]. It and has good organoleptic characteristics and, at the same time, it is a great source of vitamin C, minerals, and antioxidants, showing an excellent nutraceutical value. According to Yuyama et al. (2002), camu-camu fruits presented $3571-6112 \mathrm{mg}$ of ascorbic acid per $100 \mathrm{~g}$ of fresh pulp in the eastern region of Roraima state (Brazil). The camu-camu pulp has been exported from Peru, where most of this fruit is collected from the wild populations (Peters and Vasquez, 1986/1987). The species is distributed throughout much of the Brazilian Amazon, in the states of Pará, Amapá, Amazonas, Rondônia, Roraima, and Mato Grosso. It also occurs in Peru, Venezuela, and Colombia (McVaugh, 1963).

Camu-camu cultivation is an alternative to increase the availability of fruits, since flowering occurs all the year round, and fruit bearing is more pronounced periods coinciding with the end of the dry and the beginning of the 
rainy seasons. In a well established orchard with $4 \times 4$ m between plants and rows, it can expect a fruit yield from 10 to $15 \mathrm{t}$ per hectare (Calzada-Benza, 1980).

The increase of camu-camu cultivation with selected genetic material has been a challenge due to lack of agricultural credit, intensive harvesting, and the high costs of transportation from forests to major market centers (Peters et al., 1989). In this sense, camu-camu cultivation can represent a new crop option, requiring low investment compared to other fruits, because of their plasticity and adaptation to different environments. In this way, in an attempt to increase supplies of the fruit in more convenient locations, the Peruvian government promoted the domestication of M. dubia, through the 1996 Programa Nacional de Camu Camu (PNCC) (Penn, 2004).

The species occurrence is typical of the floodplain forests of the Amazon, characterized by periods of inundation, and can be cultivated in tropical and humid climate. It occurs in Af climate according to Köppen classification, with an average annual temperature of $26.7^{\circ} \mathrm{C}$, an average annual rainfall around $2,419 \mathrm{~mm}$, and over $88 \%$ of relative humidity (Ribeiro, 1976). In regions with transitional forest, the rainfall is clearly lower than in areas of tropical rainforest, and climate type are characterized by Am, which has small dry period according to the previous climatic classification. The average annual temperature is $28^{\circ} \mathrm{C}$ and relative humidity of $72 \%$. The predominant soils in the area are the Oxisols and ultisols with low fertility and medium texture.

The objective of this experiment was to select, through vegetative development and initial production data, 6 subsamples of camu-camu from the germplasm collection of the Instituto Nacional de Pesquisas da AmazoniaINPA (Amazonas state), located in the transition savanna/forest in the city of Mucajaí, Roraima state, Brazil.

\section{Methods}

\subsection{Location of the Study and Climatic Data}

The study was conducted at the experimental field of Serra da Prata, belonging to State owned Empresa Brasileira de Pesquisa Agropecuária-EMBRAPA, in Mucajaí (Roraima state), Brazil, whose geographical location of the experimental area is located on $60^{\circ} 58^{\prime} 40^{\prime \prime} \mathrm{W} ; 2^{\circ} 23^{\prime} 49^{\prime \prime} \mathrm{N}$.

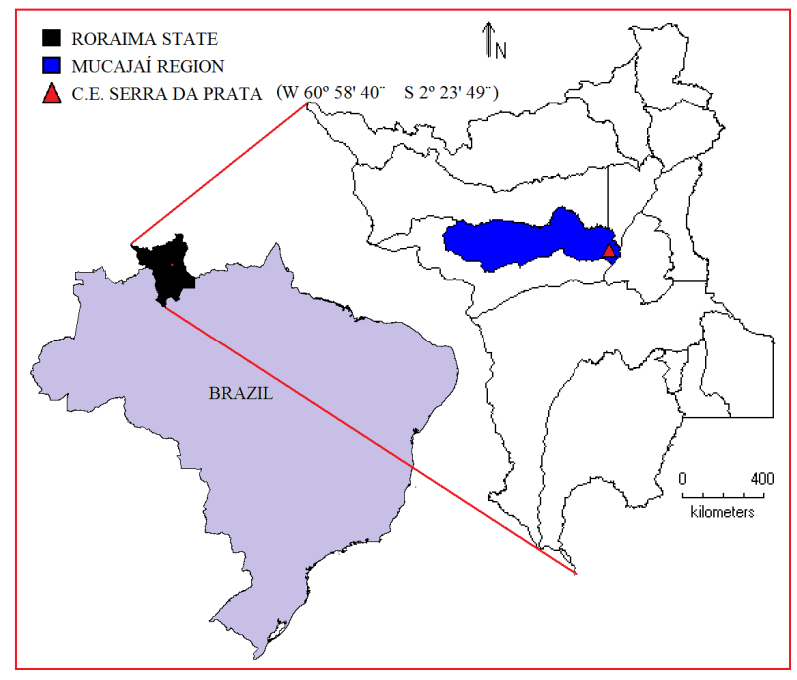

Figure 1. Location of the study

The climate is Am type, according to Köppen classification system, with a small dry season. The rainy season goes from April to August, while the dry season runs from September to March. The rainfall regime is characterized by the concentration of rainfall (about $58 \%$ of total precipitation) in the months of May, June, and July, representing the period of greatest rainfall. The period of lowest rainfall is over, 6 months, between October and March, representing about $18 \%$ of total precipitation. An intermediate period is represented in the months of April, August, and September, with about 30\% of total precipitation (Mourão, 2006). The total annual rainfall in the experimental field Serra da Prata region oscillates, in a confidence interval, on the order of 1510-2145 mm per year, with an annual average 1,844 mm (Mourão, 2003). 


\subsection{Data Collection}

Camu-camu subsamples were evaluated by measuring vegetative growth and initial production. The four vegetative parameters used in this study were the basal trunk diameter $(\mathrm{mm})$ at $10 \mathrm{~cm}$ distance from the ground level, the plant height $(\mathrm{cm})$, and the numbers of basal and terminal shoots. For the production parameters, the numbers of flowers and fruits were also counted.

Measurements were performed at intervals of 90 days during 30 months in order to define the growth curve of each subsample

\subsection{Cultivation}

The experimental area was established on an utilsol soil and plain relief, and initially, soil management consisted basically of liming with dolomitic limestone, 30 days before planting, in the amount of $2 \mathrm{t} / \mathrm{ha}$, and incorporated with natural phosphate and potassium chloride in the amount of $90 \mathrm{~kg} / \mathrm{ha}$ of $\mathrm{P}_{2} \mathrm{O}_{5}$ and $90 \mathrm{~kg} / \mathrm{ha}$ of $\mathrm{K}_{2} \mathrm{O}$ (Villachica, 1996). Green manure crops were used between rows 30 days after planting with legumes - sunn hemp (Crotalaria juncea L.); jack bean (Cannavalia ensiformis (L.) DC -), sunflower (Helianthus annuus L.), and millet (Pennisetum glaucum (L.) R.Br.) planted for physical and chemical soil conditioning.

One year after planting, $30 \mathrm{~g}$ of potassium chloride, $30 \mathrm{~g}$ of urea, and $10 \mathrm{~g}$ of micronutrients formula was applied per plant during the rainy season, once a year. Irrigation was done by the method of micro sprinklers during the driest period of the year. The herbaceous control was done using motorized knapsack brush cutter in the rows and by tractor between the lines.

\subsection{Experimental Design}

The experimental design was a randomized block design with subdivided time analysis, totaling 9 evaluations every 3 months, 6 subsamples, 4 replications and 4 plants per plot at a spacing of $5 \times 2 \mathrm{~m}$. This design was selected because it is suitable to compare subsamples, eliminating possible influence by other extraneous factors, such as soil fertility, thus reducing error with the block factor.

Regarding the study variables, the basal trunk diameter and the plant height were measured with a digital caliper and a measuring tape, respectively, meanwhile the numbers of basal and terminals shoots, as well as the numbers of flowers and fruits, were calculated by counting.

The data obtained every 3 months were subjected to analysis of variance by F-test, because of the type of data which indicates normal distribution and with increasing tendency during time. The grouping means test was analyzed by Scott-Knott test at 5\% probability. This test was used because it allows us to better discriminate the differences between subsamples.

The growth curve for each parameter was performed by polynomial regression analysis by INFO- GEN program (Balzarini \& Di Rienzo, 2011) by adjusting the curve analyzing the coefficient of determination (R2).

\section{Results}

\subsection{Basal Trunk Diameter}

The camu-camu subsamples with the best development in basal trunk diameter in the study, i.e., UAT 1896-7, UAT 1096-5, UAT 1596-7, and UAT 0796-5, showed statistically significant data and they were the best fitted to the linear model curve. Conversely, the UAT 1796-7 and URUBU-2 subsamples, with smaller basal trunk diameter than the remaining, showed no significant data. The Figure 1 represents the graphic models obtained in statistical analysis.

As shown in Table 1, the Scott-Knott mean test over time revealed that UAT 1896-7 subsample stood out with a significant difference, regarding basal trunk diameter, compared to the others from 6 to 12 months after planting. At 12 months after planting, the UAT 1896-7 subsample showed a basal trunk diameter of $21.25 \mathrm{~mm}$, higher than the other subsamples. The remaining subsamples showed no significant difference between them, ranging from 11.79 to $14.81 \mathrm{~mm}$ in UAT 1596-7 and UAT 1096-5, respectively. The UAT 1896-7 and UAT 1096-5 subsamples stood out from the other subsamples, with significant values in this parameter, from 15 to 30 months after planting. At 30 months after planting, the UAT 1896-7 and the UAT 1096-5 subsamples showed basal trunk diameters ranging from $29.13 \mathrm{~mm}$ and $30.38 \mathrm{~mm}$, respectively; the other subsamples had basal trunk diameters with no significant differences between each other in the same period, ranging from 19.19 to $23.88 \mathrm{~mm}$ with URUBU-2 and UAT 1796-7, respectively. 
Table 1. Mean data for basal trunk diameter (mm) of 6 subsamples for 30 months after planting in transition savanna/forest area, Mucajaí-RR, Brazil

\begin{tabular}{ccccccc}
\hline \multirow{2}{*}{ Months after planting } & \multicolumn{7}{c}{ Subsamples } \\
\cline { 2 - 7 } & UAT 0796-8 & UAT 1096-5 & UAT 1596-7 & UAT 1796-7 & UAT 1896-7 & URUBU-2 \\
\hline $\mathbf{6}$ & $11,15 \mathrm{~b}$ & $12,45 \mathrm{~b}$ & $12,52 \mathrm{~b}$ & $10,65 \mathrm{~b}$ & $17,14 \mathrm{a}$ & $10,53 \mathrm{~b}$ \\
$\mathbf{9}$ & $11,74 \mathrm{~b}$ & $13,33 \mathrm{~b}$ & $11,20 \mathrm{~b}$ & $11,56 \mathrm{~b}$ & $20,83 \mathrm{a}$ & $11,81 \mathrm{~b}$ \\
$\mathbf{1 2}$ & $12,95 \mathrm{~b}$ & $14,81 \mathrm{~b}$ & $11,79 \mathrm{~b}$ & $12,25 \mathrm{~b}$ & $21,25 \mathrm{a}$ & $12,66 \mathrm{~b}$ \\
$\mathbf{1 5}$ & $13,88 \mathrm{~b}$ & $18,31 \mathrm{a}$ & $13,50 \mathrm{~b}$ & $14,50 \mathrm{~b}$ & $22,50 \mathrm{a}$ & $14,13 \mathrm{~b}$ \\
$\mathbf{1 8}$ & $16,38 \mathrm{~b}$ & $22,75 \mathrm{a}$ & $16,25 \mathrm{~b}$ & $15,75 \mathrm{~b}$ & $25,50 \mathrm{a}$ & $14,75 \mathrm{~b}$ \\
$\mathbf{2 1}$ & $19,78 \mathrm{~b}$ & $24,56 \mathrm{a}$ & $17,88 \mathrm{~b}$ & $18,41 \mathrm{~b}$ & $28,75 \mathrm{a}$ & $16,75 \mathrm{~b}$ \\
$\mathbf{2 4}$ & $20,79 \mathrm{~b}$ & $26,95 \mathrm{a}$ & $20,03 \mathrm{~b}$ & $19,50 \mathrm{~b}$ & $28,75 \mathrm{a}$ & $16,75 \mathrm{~b}$ \\
$\mathbf{2 7}$ & $21,19 \mathrm{~b}$ & $28,19 \mathrm{a}$ & $19,75 \mathrm{~b}$ & $19,50 \mathrm{~b}$ & $28,88 \mathrm{a}$ & $17,06 \mathrm{~b}$ \\
$\mathbf{3 0}$ & $23,88 \mathrm{~b}$ & $30,38 \mathrm{a}$ & $23,00 \mathrm{~b}$ & $20,00 \mathrm{~b}$ & $29,13 \mathrm{a}$ & $19,19 \mathrm{~b}$ \\
\hline
\end{tabular}

On the same line with lowercase letter do not differ statistically at $5 \%$ by the Scott-Knott test.

\subsection{Plant Height}

As seen in Figure 2, the UAT 1896-7, UAT 0796-8, and URUBU-2 subsamples were the best fitted to a quadratic growth model. Meanwhile, the plant height curves of the UAT 1596-7, UAT 1096-5, and UAT 1796-7 subsamples were fitted the linear model.

Regarding the plant height over time of each subsample, Figure 2 also shows that, on the one hand, the subsamples that showed greater height development (UAT 1896-7, UAT 1596-7, and UAT 1096-5) were best fitted to the linear model curve and, on the other hand, subsamples with lower height growth (UAT 0796-8 and UAT 1796-7) were fitted to quadratic curve model and; finally, URUBU-2 subsample was adjusted to the linear model.

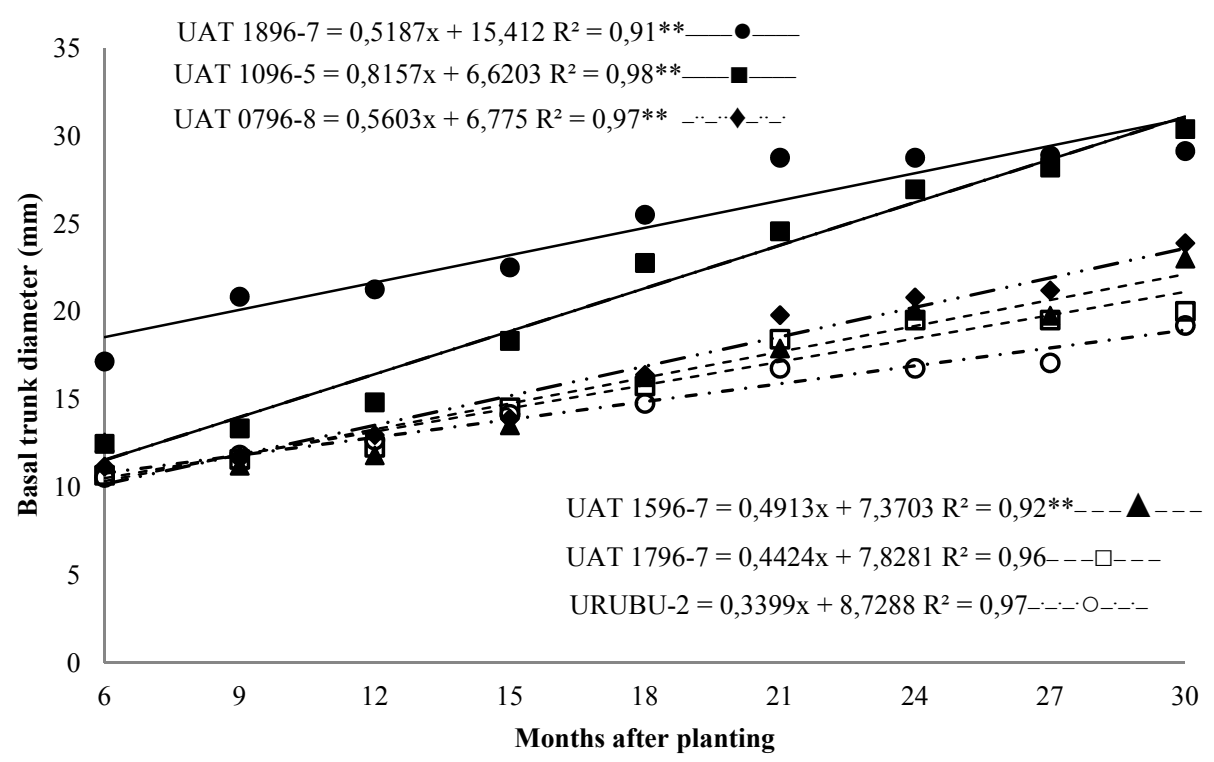

Figure 2. Growth curves of the basal trunk diameter $(\mathrm{mm})$ obtained every 3 months for 30 months after planting in transition savanna/forest area, Mucajaí-RR, Brazil

In the first evaluation at 6 months after planting, there was no significant difference among the 6 tested subsamples, ranging from 39.69 to $60.06 \mathrm{~cm}$, with UAT1796-7 UAT and 1596-7, respectively. From 9 to 27 
months after planting, all subsamples had no statistic difference. Only at 30 months is that significant difference was observed in the height of UAT 1096-5 and UAT 1596-7 subsamples compared to the others, with mean values of 235.53 and $219.63 \mathrm{~cm}$, respectively.

Table 2. Average plant height data of six subsamples for thirty months after planting in transition savanna/forest area, Mucajaí-RR, Brazil

\begin{tabular}{ccccccc}
\hline \multirow{2}{*}{ Months after planting } & \multicolumn{7}{c}{ Subsamples } \\
\cline { 2 - 7 } & UAT 0796-8 & UAT 1096-5 & UAT 1596-7 & UAT 1796-7 & UAT 1896-7 & URUBU-2 \\
\hline $\mathbf{6}$ & $48,31 \mathrm{a}$ & $49,00 \mathrm{a}$ & $60,06 \mathrm{a}$ & $39,69 \mathrm{a}$ & $57,05 \mathrm{a}$ & $50,5^{\mathrm{a}}$ \\
$\mathbf{9}$ & $63,50 \mathrm{a}$ & $64,13 \mathrm{a}$ & $68,75 \mathrm{a}$ & $78,25 \mathrm{a}$ & $69,75 \mathrm{a}$ & $58,19^{\mathrm{a}}$ \\
$\mathbf{1 2}$ & $95,25 \mathrm{a}$ & $102,38 \mathrm{a}$ & $81,88 \mathrm{a}$ & $84,88 \mathrm{a}$ & $101,25 \mathrm{a}$ & $91,56^{\mathrm{a}}$ \\
$\mathbf{1 5}$ & $114,42 \mathrm{a}$ & $129,14 \mathrm{a}$ & $106,38 \mathrm{a}$ & $97,00 \mathrm{a}$ & $139,13 \mathrm{a}$ & $111,25^{\mathrm{a}}$ \\
$\mathbf{1 8}$ & 149,44 & 161,13 & 127,38 & 98,75 & 155,45 & 123,81 \\
$\mathbf{2 1}$ & $162,94 \mathrm{a}$ & $180,88 \mathrm{a}$ & $155,88 \mathrm{a}$ & $137,94 \mathrm{a}$ & $178,5 \mathrm{a}$ & $146,49^{\mathrm{a}}$ \\
$\mathbf{2 4}$ & $172,62 \mathrm{a}$ & $190,97 \mathrm{a}$ & $165,72 \mathrm{a}$ & $143,72 \mathrm{a}$ & $181,61 \mathrm{a}$ & $155,25^{\mathrm{a}}$ \\
$\mathbf{2 7}$ & $176,13 \mathrm{a}$ & $205,13 \mathrm{a}$ & $192,25 \mathrm{a}$ & $120,63 \mathrm{a}$ & $177,00 \mathrm{a}$ & $151,92^{\mathrm{a}}$ \\
$\mathbf{3 0}$ & $138,75 \mathrm{~b}$ & $235,53 \mathrm{a}$ & $219,63 \mathrm{a}$ & $158,75 \mathrm{~b}$ & $194,63 \mathrm{~b}$ & $164,54 \mathrm{~b}$
\end{tabular}

On the same line with lowercase letter do not differ statistically at $5 \%$ by the Scott-Knott test.

\subsection{Number of Basal Shoots}

The number of basal shoots had no significant data for polynomial regression during the evaluation on time. However, by evaluating with mean test over time, there was a statistical difference in the UAT 1896-7 subsample in relation to the others (Table 3 ).

Table 3. Average number of basal shoots of six subsamples for thirty months after planting in transition savanna/forest area, Mucajaí-RR, Brazil

\begin{tabular}{ccccccc}
\hline \multirow{2}{*}{ Months after planting } & \multicolumn{7}{c}{ Subsamples } \\
\cline { 2 - 7 } & UAT 0796-8 & UAT 1096-5 & UAT 1596-7 & UAT 1796-7 & UAT 1896-7 & URUBU-2 \\
\hline $\mathbf{6}$ & $1,75 \mathrm{~b}$ & $2,5 \mathrm{~b}$ & $1,5 \mathrm{~b}$ & $2 \mathrm{~b}$ & $4,31 \mathrm{a}$ & $2,38 \mathrm{~b}$ \\
$\mathbf{9}$ & $1,5 \mathrm{~b}$ & $2,75 \mathrm{~b}$ & $1,63 \mathrm{~b}$ & $2,38 \mathrm{~b}$ & $5,13 \mathrm{a}$ & $2,5 \mathrm{~b}$ \\
$\mathbf{1 2}$ & $1,38 \mathrm{~b}$ & $2,13 \mathrm{~b}$ & $1,81 \mathrm{~b}$ & $2,13 \mathrm{~b}$ & $4,38 \mathrm{a}$ & $1,98 \mathrm{~b}$ \\
$\mathbf{1 5}$ & $1,5 \mathrm{~b}$ & $1,88 \mathrm{~b}$ & $1,5 \mathrm{~b}$ & $2,63 \mathrm{~b}$ & $4,38 \mathrm{a}$ & $2,00 \mathrm{~b}$ \\
$\mathbf{1 8}$ & $1,75 \mathrm{~b}$ & $2,13 \mathrm{~b}$ & $1,75 \mathrm{~b}$ & $2,38 \mathrm{~b}$ & $4,70 \mathrm{a}$ & $1,75 \mathrm{~b}$ \\
$\mathbf{2 1}$ & $1,75 \mathrm{c}$ & $3,00 \mathrm{~b}$ & $1,81 \mathrm{c}$ & $2,38 \mathrm{~b}$ & $4,44 \mathrm{a}$ & $1,69 \mathrm{c}$ \\
$\mathbf{2 4}$ & $1,75 \mathrm{c}$ & $3,00 \mathrm{~b}$ & $1,81 \mathrm{c}$ & $2,38 \mathrm{~b}$ & $4,44 \mathrm{a}$ & $1,69 \mathrm{c}$ \\
$\mathbf{2 7}$ & $2,00 \mathrm{~b}$ & $2,88 \mathrm{~b}$ & $2,00 \mathrm{~b}$ & $2,38 \mathrm{~b}$ & $4,69 \mathrm{a}$ & $1,75 \mathrm{~b}$ \\
$\mathbf{3 0}$ & $2,00 \mathrm{~b}$ & $2,63 \mathrm{~b}$ & $2,00 \mathrm{~b}$ & $2,38 \mathrm{~b}$ & $4,69 \mathrm{a}$ & $1,81 \mathrm{~b}$ \\
\hline
\end{tabular}

On the same line with lowercase letter do not differ statistically at $5 \%$ by the Scott-Knott test.

\subsection{Number of Terminal Shoots}

The best developments in the number of terminal shoots were observed in the UAT 1896-7, UAT 1096-5, UAT 0796-5, and URUBU-2 subsamples, which showed significant data and the best fitted curve linear model. The UAT 1796-7 and UAT 1596-7 subsamples, which showed lower values of terminal shoots, showed no significant data that could be represented by a model of the growth curve. The Figure 3 represents the graphic models obtained in statistical analysis (Figure 3). 


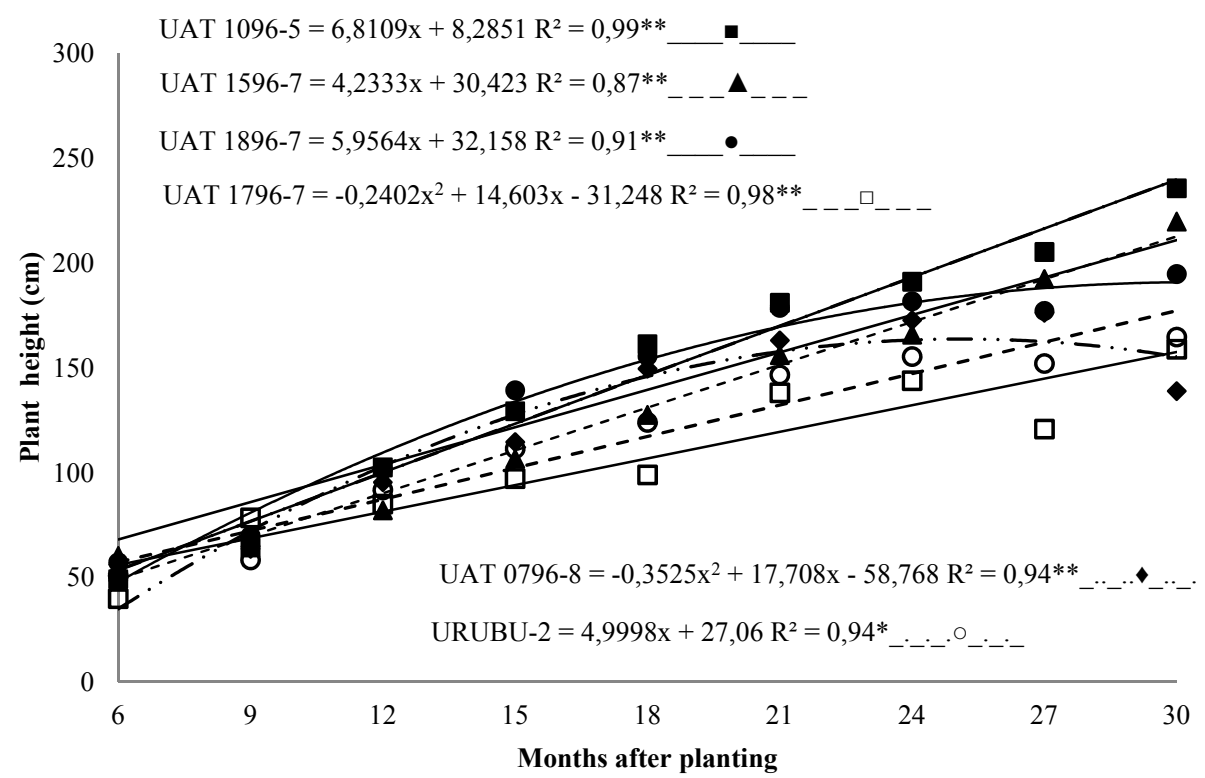

Figure 3. Growth curves of plant height $(\mathrm{cm})$ obtained every 3 months for 30 months after planting in transition savanna/forest area, Mucajaí-RR, Brazil

At 6 months after planting, the number of terminal shoots did not differ statistically between all tested subsamples, ranging from 1.88 to 6.63 shoots, showing uniformity between plants. From 9 to 15 months after planting, the superiority of UAT 1896-7 subsample remained in comparison to other subsamples. The UAT 1896-7, UAT 1096-5, and UAT 0796-8 had the best rates for numbers of terminal shoots in the study from 18 to 30 months after planting. At 30 months after planting, UAT 1096-5, UAT 1896-7, and UAT 0796-7 stood out from the others with values of $80.71,80.13$ and 56.13 shoots, respectively, showing statistical difference of other subsamples (Table 4).

Table 4. Average number of terminal shoots of six subsamples for thirty months after planting transition savanna/forest area, Mucajaí-RR, Brazil

\begin{tabular}{ccccccc}
\hline \multirow{2}{*}{ Months after planting } & \multicolumn{7}{c}{ Subsamples } \\
& UAT 0796-8 & UAT 1096-5 & UAT 1596-7 & UAT 1796-7 & UAT 1896-7 & URUBU-2 \\
\hline $\mathbf{6}$ & $1,88 \mathrm{a}$ & $5,63 \mathrm{a}$ & $3,13 \mathrm{a}$ & $6,00 \mathrm{a}$ & $6,63^{\mathrm{a}}$ & $2,25 \mathrm{a}$ \\
$\mathbf{9}$ & $13,13 \mathrm{~b}$ & $11,88 \mathrm{~b}$ & $8,75 \mathrm{~b}$ & $15,38 \mathrm{~b}$ & $32,25 \mathrm{a}$ & $9,81 \mathrm{~b}$ \\
$\mathbf{1 2}$ & $11,75 \mathrm{~b}$ & $20,38 \mathrm{~b}$ & $15,75 \mathrm{~b}$ & $14,25 \mathrm{~b}$ & $30,75 \mathrm{a}$ & $13,83 \mathrm{~b}$ \\
$\mathbf{1 5}$ & $32,63 \mathrm{a}$ & $46,13 \mathrm{a}$ & $28,5 \mathrm{~b}$ & $35,5 \mathrm{~b}$ & $70,38 \mathrm{a}$ & $28,5 \mathrm{~b}$ \\
$\mathbf{1 8}$ & $36,56 \mathrm{a}$ & $45,81 \mathrm{a}$ & $24,63 \mathrm{~b}$ & $24,75 \mathrm{~b}$ & $52,25 \mathrm{a}$ & $21,56 \mathrm{~b}$ \\
$\mathbf{2 1}$ & $45,00 \mathrm{~b}$ & $58,63 \mathrm{a}$ & $29,19 \mathrm{~b}$ & $25,38 \mathrm{~b}$ & $70,44 \mathrm{a}$ & $26,39 \mathrm{~b}$ \\
$\mathbf{2 4}$ & $46,52 \mathrm{a}$ & $56,87 \mathrm{a}$ & $28,01 \mathrm{~b}$ & $25,31 \mathrm{~b}$ & $72,24 \mathrm{a}$ & $27,32 \mathrm{~b}$ \\
$\mathbf{2 7}$ & $47,25 \mathrm{~b}$ & $69,63 \mathrm{a}$ & $27,88 \mathrm{~b}$ & $24,00 \mathrm{~b}$ & $69,23 \mathrm{a}$ & $27,65 \mathrm{~b}$ \\
$\mathbf{3 0}$ & $80,25 \mathrm{a}$ & $80,71 \mathrm{a}$ & $33,52 \mathrm{~b}$ & $30,00 \mathrm{~b}$ & $80,13 \mathrm{a}$ & $29,03 \mathrm{~b}$
\end{tabular}

On the same line with lowercase letter do not differ statistically at $5 \%$ by the Scott-Knott test.

\subsection{Precocity}

At 21 months after planting, the UAT 1596-7, UAT 1096-5, UAT 0796-8, and UAT 1896-7 subsamples had a total of 96, 25, 20 and 18 flowers, respectively. At 27 months after planting, only 2 subsamples flowered, UAT 1096-5 and UAT 0796-8, with 25 and 3 flowers, respectively. 


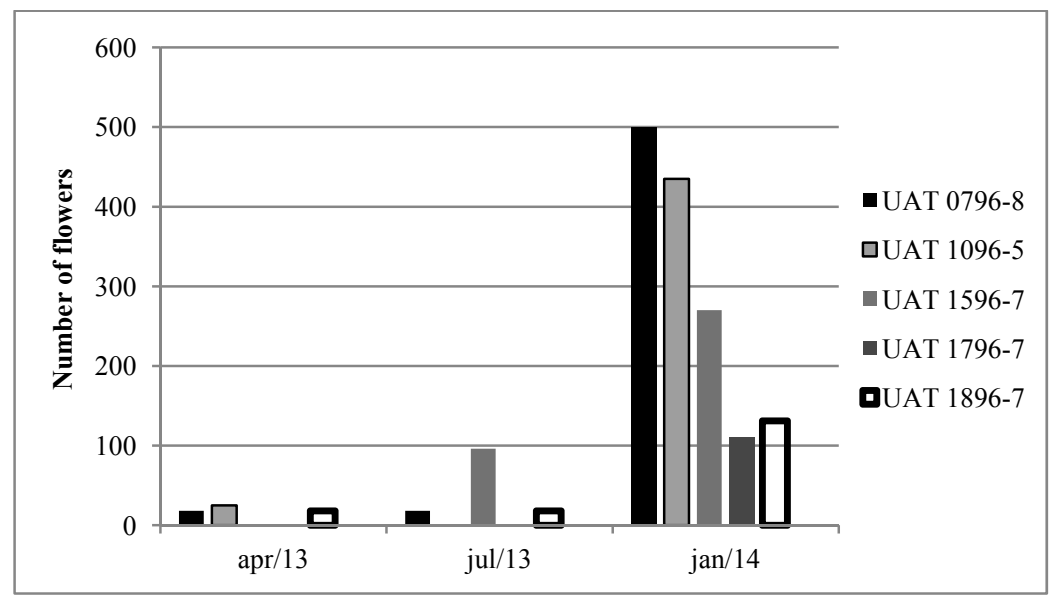

Figure 4. Total number of flowers of 6 subsamples obtained every three months for 30 months after planting in transition savanna/forest area, Mucajaí-RR, Brazil

Peak flowering occurred in January, 30 months after planting. The UAT 0796-8 and UAT 1096-5 subsamples, with 500 and 435 flowers in total, respectively, stood out over the remaining. The other subsamples, UAT 1596-7, UAT 1796-7, and UAT 1896-7, showed satisfactory flowering, with 270, 131, and 110 flowers, respectively. The URUBU-2 subsample showed no flowering, with late flowering characteristic (Figure 4).

\section{Discussion}

Based on the parameters of vegetative growth and precocity the subsamples tested present different growing, flowering and fruiting patterns.

The number of basal shoots was recorded for analysis of canopy formation, since the larger the number of basal shoots, the greater the possibility of having terminal shoots which are able to bear fruit. The number of basal shoots has medium heritability levels (in the narrow sense): $\mathrm{h} 2 \mathrm{a}=0.45$ and $=0.33 \mathrm{~h} 2 \mathrm{~g}$ in a broad sense, and that this variable is significantly correlated with fruit production $(\mathrm{R} 2=0.43)$, fruit weight $(\mathrm{R} 2=0.38)$, and ascorbic acid (Pinedo, 2013).

According to Pinedo et al. (2011), plants of the MD-013, MD-014, MD-015, MD-017, and MD-020 clones from the Loreto state (Iquitos, Peru), stood out as promising genotypes of Nanay and Itaya rivers. Thus, the plants showed basal trunk diameters ranging from 22.0 to $25.6 \mathrm{~mm}$ at 4 years after planting; the subsamples of Uatumã river (Amazonas state, Brazil) analised in this study grew better than those of Nanay and Itaya rivers in basal trunk diameter, because diameters ranged from 29.13 to $30.38 \mathrm{~mm}$ in the transition savanna/forest at 30 months after planting. These data support the results obtained from Siviero et al (2012), who observed that basal trunk diameter at $10 \mathrm{~cm}$ from the ground of two-years-old plants grown from seeds in Acre Brazilian state, ranged from 14.58 to $33.85 \mathrm{~mm}$. Moreover, Ribeiro et al. (2000) concluded that matrices planted from seeds of the Solimões river in Belém (Pará state, Brazil), with 2 years of planting, showed basal shoot diameters, measured at a height of $60 \mathrm{~cm}$ above the ground level, much greater than that observed with clones in the transition savanna/forest area, ranging from 97.6-119.7 $\mathrm{mm}$ and $128-166 \mathrm{~mm}$ at 2 and 3 years after planting, respectively. In the present study, at 30 months after planting, height ranged from 1.49 to $2.35 \mathrm{~m}$ in the transition savanna/forest area, results which are consistent with Ribeiro et al. (2000), who observed that plants, 2 years after planting, ranged from 1.42 to $1.96 \mathrm{~m}$ in height, and from 1.93 to $2.82 \mathrm{~m}$ after 3 years of planting in Belém, Pará state Brazil.

In relation with the fruit production, according to Peters and Hammonds (1990), fruit bearing starts when the plant reaches basal trunk diameter of $2.0 \mathrm{~cm}$. At 21 months after planting, the UAT 0796-8, UAT 1896-7 and UAT 1096-5 subsamples showed the first fruits and basal trunk diameters of 19,78, 28,75 and 24,56 mm, respectively.

According to Pinedo and Paredes (2012), plants that stood out with high values of vegetative parameters for the first 3 years did not repeat the high level in the years to produce fruit, leaving in doubt the applicability of early evaluation of subsamples based on vegetative parameters to predict capacity production of plants or progenies of camu-camu. However, in this same experiment, 21, 37, 68, 211, and 222 progenies, presented good vegetative and production parameters in 2 years of evaluation (2010-2011). 
According to Gil et al. (2011), the E3-F7 subsample demonstrated that it is not necessary a great height or number of secondary shoots in vegetative evaluation to achieve high yields of marketable fruits. In this case, the secondary shoots are those measured at $50 \mathrm{~cm}$ above ground level.

The basal trunk diameter is directly associated with the fruit yield. This was demonstrated by Peters and Vasquez (1986/1987) who also found that flower production and fruit yield exponentially increase with increasing basal trunk diameter of camu-camu.

We could recommend, in a preliminary way, the UAT 1096-5 subsample such as that developed in the best position to transition savanna/forest area, with higher terminal shoots, superior height, early flowering, and higher number of flowers than the remaining camu-camu subsamples.

At 30 months after planting, the UAT 1896-7 and 0796-8 subsamples showed the number of terminal shoots with no statistical difference from the UAT 1096-5, but had slightly lower height, which was statistically significant.

The UAT 1596-7, UAT 1796-7, and URUBU-2 subsamples showed lower values of number of terminal shoots, although UAT 1596-7 presented greater height.

The subsamples presented good adaptability to upland conditions, in the transition savanna/forest of Roraima state, with utilsols and supplementary irrigation over the 3 months of lowest rainfall. The possibility of cultivation in these areas can represent an opportunity of rural development, since camu-camu is a nutraceutical species that holds high commercial expectations. To overcome the 21 months of vegetative growth with no production an intercrop with annual species such as beans, cassava, watermelon and corn is indicated to generate income for the investment in irrigation and soil management.

\section{References}

Balzarini, M. G., \& Di Rienzo, J. A. (2012). InfoGen versión Software estadístico para el análisis de datos genéticos. FCA, Universidad Nacional de Córdoba, Argentina.

Calzada Benza, J. C. (1980). Frutales nativos (p. 314). La Molina: El Estudiante.

Gil, O. J. A., Rodriguez, C. A., Cruz, C. O., Sangama, D. P. Z., \& Wong, J. A. C. (2011). Evaluación agronómica de cuatro clones de camu camu (Myrciaria dubia (H.B.K) Mc Vaugh) en un suelo aluvial inundable de la región Ucayali. Invest. Amaz., 1(2), 70-77.

Martin, M. P., Peters, C. M., \& Ashton, M. S. (2014). Revisiting Camu-camu (Myrciaria dubia): Twenty-seven Years of Fruit Collection and Flooding at an Oxbow Lake in Peruvian Amazonia. Econ Bot, 20(10), 1-8.

McVaugh, R. (1963). Tropical American Myrtaceae. II. Field Museum of Natural History, Botanical Series, 29, 315-532.

Mourão, M., Moura Neto, M. A. de, Bendahan, A. B., Xaud, M. R., \& Xaud, H. A. M. (2006). Probabilidade de precipitação pluvial mensal no campo Experimental Serra da Prata, Mucajaí (1993-2005). Boletim de Pesquisa e Desenvolvimento (No. 6, p. 18). Boa Vista: Embrapa Roraima.

Mourão, M., Xaud, M. R., Xaud, H. A. M., Moura Neto, M. A., Arco-Verde, M. F., Pereira, P. R. V. S., \& Tonini, H. (2003). Precipitação pluviométrica em áreas de transição savana-mata de Roraima: campos experimentais Serra da Prata e Confiança. Comunicado Técnico (p. 7). Boa Vista: Embrapa Roraima.

Penn, J. W. (2006). The cultivation of camu camu (Myrciaria dubia): A tree planting programme in the peruvian amazon. Forests, Trees and Livelihoods, 16, 85-101. http://dx.doi.org/10.1080/14728028.2006.9752547

Peters, C. M., Balick, M. J., Kahn, F., \& Anderson, A. B. (1989). Oligarchic forests of economic plants in Amazonia: Utilization and conservation of an important tropical resource. Cons Bio, 4, 341-349. http://dx.doi.org/10.1111/j.1523-1739.1989.tb00240.x

Peters, C. M., \& Hammonds, E. J. (1990). Fruits from the flooded forests of Peruvian Amazonia: Yield estimates for natural populations of three promising species. Advin Econ Bot, 8, 159-176.

Peters, C. M., \& Vásquez, A. (1986/1987). Estudios ecológicos de camu-camu (Myrciaria dubia). I. Producción de frutos en poblaciones naturales. Act Amaz, 16/17, 161-174.

Pinedo, M. P. (2013). Correlation and heritability analysis in breeding of camu-camu [Myrciaria dubia (Kunth) McVaugh]. Afr. J. Plant Sci., 7(2), 61-66. http://dx.doi.org/10.5897/AJPS12.023

Pinedo, M. P., \& Paredes, E. D. (2011). Evaluación Preliminar de 108 Progenies Precoces de Camu-Camu Myrciaria dubia (Myrtaceae) en Loreto, Peru. Fol Amaz, 20, 77-82. 
Pinedo, S., Iman, S., Pinedo, M., Vasquez, A., \& Collazos, H. (2011). Clonal trial of five genotypes of "camu-camu"Myrciaria dubia (Kunth) Mc. Vaugh, in non-flooded area. Afr. J. Plant Sci., 5, 40-46.

Ribeiro, M. N. G. (1976). Aspectos climatológicos de Manaus. Act Amaz, 2, 229-233.

Ribeiro, S. L., Silva, J. F., Mota, M. G. C., \& Corrêa, M. L. P. (2000). Avaliação de acessos de camu-camuzeiro em terra firme. Comun. téc (No. 17, pp. 1-4).

Siviero, A., Oliveira, L. C. de, Pereira, A. A. A., Mendonça, A. S., Nascimento, F. S. S. do, \& Yuyama, K. (2012). Introdução e avaliação de camu-camu (Myrciaria dubia) no Acre. Proccedings of Congresso Brasileiro De Recursos Genéticos. Belém, PA; Brasil. Sociedade Brasileira de Recursos Genéticos, CD ROM.

Villachica, L. H. (1996). El cultivo del camu camu (Myrciaria dubia (H.B.K.) McVaugh) en la Amazonia Peruana. Tratado de Cooperación Amazonica (p. 95). Iquitos, Peru.

Yuyama, K., Aguiar, J. P. L., \& Yuyama, L. K. O. (2002). Camu-camu: Um fruto fantástico como fonte de vitamina C. Manaus: Acta Amazônica, 32(1), 169-174.

\section{Notes}

Note 1. This experiment will be evaluated until the solid data of production could be estimated.

\section{Copyrights}

Copyright for this article is retained by the author(s), with first publication rights granted to the journal.

This is an open-access article distributed under the terms and conditions of the Creative Commons Attribution license (http://creativecommons.org/licenses/by/3.0/). 